International Journal of Biological Research, $2(2)(2014) 35-38$
International Journal of Biological Research
Journal home page: $\begin{gathered}\text { www.sciencepubco.com/index.php/IJBR } \\ \text { doi: } 10.14419 / \text { ijbr.v2i2.2835 } \\ \text { Research Paper }\end{gathered}$

\title{
Prevalence of subclinical mastitis and its association with bacteria and risk factors in lactating cows of Barisal district in Bangladesh
}

\author{
Kayesh MEH $^{1}{ }^{*}$, Talukder $M^{2}$, Anower AKMM ${ }^{1}$ \\ ${ }^{1}$ Department of Microbiology, Faculty of Animal Science and Veterinary Medicine, \\ Patuakhali Science and Technology University, Bangladesh \\ ${ }^{2}$ Department of Physiology and Pharmacology, Faculty of Animal Science and Veterinary Medicine, \\ Patuakhali Science and Technology University, Bangladesh \\ *Corresponding author E-mail: mehkayesh@ pstu.ac.bd
}

\begin{abstract}
The subclinical mastitis is more serious and is responsible for much greater loss to the dairy industry in Bangladesh. This study was performed to determine the prevalence of bovine subclinical mastitis and to isolate and identify the bacterial agents and risk factors associated with subclinical mastitis in randomly selected 200 lactating cows (147 local zebu and 53 crossbreds) of Barisal district in Bangladesh. California Mastitis Test (CMT) was performed on each quarter sample of lactating cows at field condition for determination of subclinical mastitis. Out of 200 lactating cows, 57 were found to be positive for subclinical mastitis by CMT. Out of 57 CMT positive cows, only 15 cows showed strong positive reactions and these samples were used for bacteriological culture to isolate and identify bacterial agents. The overall prevalence of subclinical mastitis was $28.50 \%$. The prevalence of subclinical mastitis was significantly high in crossbreds $(45.28 \%)$ compared to local zebu $(22.45 \%)$ ( $\mathrm{p}<0.05$ ). Based on CMT results of quarters, prevalence of subclinical mastitis was $40.57 \%$ $(\mathrm{n}=212)$ in crossbreds and $20.92 \%(\mathrm{n}=588)$ in local zebu cows. The prevalence was significantly $(\mathrm{p}<0.05)$ higher in cows with a daily milk yield of 3-5L and 5-7L. The highest prevalence found in mid lactation was $32.50 \%$ and the highest prevalence in the age group of 7 to 9 years was $37.50 \%$. The prevalence of subclinical mastitis was comparatively higher $(32.69 \%)$ in lactating cows where housed with earthen floor compared to concrete floor (23.17\%). Among the pathogens isolated from the strongly positive subclinical mastitis samples, the most frequent bacteria were Staphylococcus spp. (73.33\%). For early detection of subclinical mastitis, CMT can be performed regularly as a control measure and emphasis should be given on farm management practices, particularly on milking procedure and udder sanitation.
\end{abstract}

Keywords: Bacteria, CMT, Prevalence, Risk factors, Subclinical mastitis.

\section{Introduction}

Mastitis is the inflammation of mammary gland characterized by swelling, heat, redness, hardness and pain with abnormalities in milk (Fox 2009). Mastitis is the most prevalent production disease in dairy herds world-wide and under untreated conditions, it constitutes a serious problem in dairy herds with considerable economic consequences, mainly due to fall in milk production, decreased milk quality for dairy purposes and poor milk hygiene (Seegers et al. 2003). At least, 137 infectious causes of bovine mastitis are known to date, and in large animals the commonest pathogens are Staphylococcus aureus, Streptococcus agalactiae, other Streptococcus species and Coliforms (Sumathi et al. 2008). It may also be associated with many other organisms including Actinomyces pyogenes, Pseudomonas aeroginosa, Nocardia asteroides, Clostridium perfringens and others like Mycobacterium, Mycoplasma, Pasteurella and Prototheca species, and yeasts (Radostits et al. 2007). The majority of the mastitis cases are caused by only a few common bacterial pathogens, namely, Staphylococcus species, Streptococcus species, Coliforms and Actinomyces pyogenes (Du Preeze 2000, Quinn et al. 2004).
Mastitis is mainly categorized into clinical mastitis and subclinical mastitis (Kader et al. 2003). About $75-80 \%$ mastitis is subclinical, characterized by a significantly increased leukocyte count in milk (Bradley 2002). In subclinical mastitis, there are no obvious clinical signs such as abnormal milk, udder swelling or tenderness, or systemic signs such as fever, depression. Instead there is an increase in somatic cell counts of the milk (Radostis et al. 2000). Subclinical mastitis is important due to the fact that it is 15 to 40 times more prevalent than the clinical form, is of long duration, difficult to detect, adversely affects milk quality and production of dairy animals and constitutes a reservoir of microorganisms that can affect other animals within the herd due to its contagious nature (Schultz et al. 1978). Subclinical mastitis causes more than three times losses as compared to clinical mastitis (Singh \& Singh 1994). The subclinical mastitis is more serious and causes much greater loss to the dairy industry in Bangladesh. The annual economic loss occurs due to reduced milk production alone caused by subclinical mastitis in Bangladesh has been estimated to be BDT 122.6 (US \$ 2.11) million (Kader et al. 2003).

Comprehensive reports on subclinical mastitis in Bangladesh are lacking, but a prevalence of $47 \%$ was recorded (Kader et al. 2003), and 55\% was recorded in Sahiwal cows (Ghosh et al. 2004). Besides causing huge economic losses to milk production, the sub- 
clinical mastitis remain a continuous source of infection to other herd mates, as there are no gross inflammatory changes in the udder tissue it is usually not detected until laboratory examination. If the infection persists for longer periods, then it may lead a fibrous tissue barrier between the organisms and the antibiotic preparations, thus, limiting their efficacy. Therefore, it is important to know the prevalence of subclinical mastitis in dairy herds and delineate the important factors responsible for it. California Mastitis Test (CMT) has been recognized as a highly sensitive test to detect bovine subclinical mastitis (Dangore et al. 2000, Sachin \& Suresh 2006, Madut et al. 2009). So far, there is no report on prevalence of subclinical mastitis in lactating cows of Barisal district, Bangladesh. Therefore, the study was undertaken to determine the prevalence of subclinical mastitis and to isolate and identify the bacterial agents and risk factors associated with subclinical mastitis in lactating cows of Barisal district, Bangladesh.

\section{Materials and methods}

\subsection{Study area and study animals}

A cross-sectional study was conducted on randomly selected 200 lactating cows (147 local zebu and 53 crossbreds) of five upazilas (Babugonj, Ujirpur, Gournadi, Barisal Sadar and Bakergonj) in Barisal district of Bangladesh during the period of April 2013 to March 2014. The information on animals such as age, breed, and parity, stage of lactation and daily milk yield, and type of floor used for housing of the animals was recorded using a semistructured questionnaire by asking to the owners and/or attendants of the animals.

\subsection{Aseptic milk sample collection and physical exami- nation}

Fresh milk samples of approximately $10 \mathrm{ml}$ amount from each quarter of randomly selected apparently healthy cows were collected aseptically in separate glass tube according to the method described by Rosenberger (1979) at morning milking and the tube was labeled with the number of the cow. Immediately after collection, milk samples were subjected to physical examination with naked eyes to detect any abnormalities in color, odor, consistency and presence of clot, blood, flakes and any other visible abnormalities. These aseptically collected milk samples were used for CMT

\subsection{Determination of subclinical mastitis}

Two hundred lactating cows were tested with CMT using a CMT Kit (Leucocytest ${ }^{\circledR}$, Synbiotics Corporation, France) to detect subclinical mastitis in four quarters of the udder. The CMT was conducted according to the manufacturer's instructions. The CMT reagent reacts with DNA of epithelial and inflammatory cells present in the milk sample. CMT results were read immediately and were scored for each quarter depending on the thickness and amount of the gel formed. In this study, CMT scores of ' 0 ' and trace $( \pm)$ were taken as negative or normal whereas, CMT scores of $1+$ (weak positive), $2+$ (distinct positive) and 3+ (strong positive) were considered as indicators of subclinical mastitis. In the present study, a subclinical mastitis case was defined as an animal with at least one of the quarters with a CMT score of $\geq 1+$.

\subsection{Isolation and identification of bacterial agents}

The milk samples that showed strong positive reactions (score value $3+$ ) in CMT were taken for bacteriological culture. Isolation of bacterial agents from these samples were done by culturing the milk samples on nutrient agar, blood agar, MacConkey agar and eosin methyene blue (EMB) agar plates. The inoculated plates were incubated at $37^{\circ} \mathrm{C}$ under aerobic condition for $24-48$ hours. Identification of the bacterial agents from the pure culture were done based on their colony characteristics, Gram staining reaction, hemolysis pattern and biochemical test as described by Merchant and Packer (1967) and Cheesbrough (1985).

\subsection{Statistical analysis}

Prevalence was calculated as the number of positive cases of subclinical mastitis per 100 cows tested. The association of age, breed parity, stage of lactation, daily milk yield and type of floor with the CMT positivity was determined by Chi-square test using SPSS-17.0 software and 95\% was taken for significance level of the result.

\section{Results}

\subsection{Prevalence of bovine subclinical mastitis}

In this study, of the total 200 cows, 57 (28.50\%) were positive to CMT and of 800 active quarters, 209 (26.13\%) were positive to CMT (Table 1). Out of 57 CMT positive cases, 15 were strongly positive (score value $3+$ ), 9 were distinctly positive (score value $2+$ ) and 33 were weakly positive (score value $1+$ ). There was a variation of CMT score even in different quarters of individual lactating cattle.

Table 1: Cattle and quarter-wise prevalence of subclinical mastitis in lactating cows in Bangladesh detected by CMT

\begin{tabular}{llll}
\hline Types & Sample tested & Positive cases & Prevalence \\
\hline Cattle & 200 & 57 & $28.50 \%$ \\
Quarters & 800 & 209 & $26.13 \%$ \\
\hline
\end{tabular}

In case of breed-wise prevalence, among the 147 local zebu, 33 (22.45\%) were positive to CMT and out of 53 crossbreds, 24 (45.28\%) were positive to CMT. Out of 588 active quarters of local zebu, $123(20.92 \%)$ and out of 212 active quarters of crossbreds, $86(40.57 \%)$ were positive to CMT (Table 2). Highly significant difference $(\mathrm{p}<0.05)$ was observed in prevalence of subclinical mastitis between local and crossbreds (Table 3 ).

Table 2: Breed and quarter-wise prevalence of subclinical mastitis in lactating cows in Bangladesh detected by CMT

\begin{tabular}{llll}
\hline Types & Sample tested & Positive cases & Prevalence \\
\hline Local zebu & 147 & 33 & $22.45 \%$ \\
Crossbreds & 53 & 24 & $45.28 \%$ \\
Quarters of local zebu & 588 & 123 & $20.92 \%$ \\
Quarters of Crossbred & 212 & 86 & $40.57 \%$ \\
\hline
\end{tabular}

In case of age-wise prevalence, the prevalence of subclinical mastitis recorded in different age groups were $28.38 \%$ (2-5 years), $25.97 \%$ (5-7 years), $31.58 \%$ (7-9 years), $37.50 \%$ (9-12 years) and $33.33 \%$ ( $>12$ years). The highest prevalence based on age groups was $37.50 \%$ found in the age group of $9-12$ years and the lowest prevalence was $25.97 \%$ found in the age group of 5-7 years (Table $3)$.

The overall prevalence of subclinical mastitis based on lactation stage in cows showed that all the three lactation stages had subclinical mastitis but, the highest prevalence of subclinical mastitis was recorded in mid lactation $(32.50 \%)$ which was followed by late $(28.17 \%)$ and early stage $(22.45 \%)$ of lactation (Table 3$)$.

The prevalence of subclinical mastitis related to parity number showed an increasing tendency with the increase of parity number. The results of prevalence of subclinical mastitis based on the parity number of cows are presented in Table 3 . Based on parity number of cows, the highest prevalence was $42.86 \%$ in $7^{\text {th }}$ parity of cows, whereas in $1^{\text {st }}$ and $2^{\text {nd }}$ parity the prevalence was $24.64 \%$ and $28.00 \%$, respectively (Table 3 ).

Based on daily milk yield, the prevalence of subclinical mastitis recorded was $18.64 \%, 24.73 \%, 43.59 \%, 71.43 \%$ and $50 \%$, in lactating cows with daily milk yield of $0.5-1.5 \mathrm{~L}, 1.5-3.0 \mathrm{~L}, 3-5 \mathrm{~L}, 5-$ $7 \mathrm{~L}$ and 7-10L, respectively. The highest prevalence of subclinical mastitis based on daily milk yield was $71.43 \%$ found in the cattle produced milk within a range of 5-7L. Cows with a daily milk 
yield of 3-5L and 5-7L had significantly $(\mathrm{p}<0.05)$ higher preva- lence of subclinical mastitis $($ Table 3$)$.

Table 3: Prevalence of bovine subclinical mastitis based on various factors

\begin{tabular}{|c|c|c|c|c|c|c|}
\hline Factors & & No. of cows tested $(n=200)$ & $\begin{array}{l}\text { Test positive } \\
(\mathrm{n}=57)\end{array}$ & Prevalence rate & Odds ratio (OR) & p-value \\
\hline \multirow{5}{*}{ Age } & $2-5$ years & 74 & 21 & $28.38 \%$ & 0.990 & 0.977 \\
\hline & $5-7$ years & 77 & 20 & $25.97 \%$ & 0.816 & 0.532 \\
\hline & $7-9$ years & 38 & 12 & $31.58 \%$ & 1.200 & 0.641 \\
\hline & $9-12$ years & 8 & 3 & $37.50 \%$ & 1.533 & 0.568 \\
\hline & $>12$ years & 3 & 1 & $33.33 \%$ & 1.258 & 0.852 \\
\hline \multirow{2}{*}{ Breed } & Local & 147 & 33 & $22.45 \%$ & & \\
\hline & Crossbreds & 53 & 24 & $45.28 \%$ & 2.86 & 0.002 \\
\hline \multirow{7}{*}{ Parity } & $1^{\text {st }}$ & 69 & 17 & $24.64 \%$ & 0.743 & 0.381 \\
\hline & $2^{\text {nd }}$ & 50 & 14 & $28.00 \%$ & 0.983 & 0.928 \\
\hline & $3^{\text {rd }}$ & 40 & 14 & $35.00 \%$ & 1.13 & 0.310 \\
\hline & $4^{\text {th }}$ & 21 & 7 & $33.33 \%$ & 1.06 & 0.605 \\
\hline & $5^{\text {th }}$ & 5 & 0 & $0 \%$ & & \\
\hline & $6^{\text {th }}$ & 8 & 2 & $25.00 \%$ & 0.969 & 0.823 \\
\hline & $7^{\text {th }}$ & 7 & 3 & $42.86 \%$ & 1.09 & 0.399 \\
\hline \multirow{3}{*}{ Stage of lactation } & Early (15-90 days) & 49 & 11 & $22.45 \%$ & 0.66 & 0.282 \\
\hline & Mid (90-180 days) & 80 & 26 & $32.50 \%$ & 1.32 & 0.306 \\
\hline & Late (>180 days) & 71 & 20 & $28.17 \%$ & 0.97 & 0.939 \\
\hline \multirow{5}{*}{ Daily milk yield } & $0.5-1.5 \mathrm{~L}$ & 59 & 11 & $18.64 \%$ & 0.54 & 0.101 \\
\hline & $1.5-3.0 \mathrm{~L}$ & 93 & 23 & $24.73 \%$ & 0.57 & 0.085 \\
\hline & $3-5 \mathrm{~L}$ & 39 & 17 & $43.59 \%$ & 2.68 & 0.008 \\
\hline & $5-7 \mathrm{~L}$ & 7 & 5 & $71.43 \%$ & 6.77 & 0.025 \\
\hline & $7-10 \mathrm{~L}$ & 2 & 1 & $50.00 \%$ & 2.53 & 0.513 \\
\hline \multirow{3}{*}{ Type of floor } & Earthen & 104 & 34 & $32.69 \%$ & 1.54 & 0.173 \\
\hline & Concrete & 82 & 19 & $23.17 \%$ & 0.63 & 0.166 \\
\hline & Slatted & 14 & 4 & $28.57 \%$ & 1.00 & 0.995 \\
\hline
\end{tabular}

In this study, the prevalence of bovine subclinical mastitis was found to be influenced by type of floor used for lactating cows. Cows that were sampled having earthen floor had considerably higher risks of subclinical mastitis than cows reared in concrete floor system. The prevalence of subclinical mastitis was higher $(32.69 \%)$ in lactating cows with earthen floor compared to the cows that kept in house with slatted floors (28.57\%) and concrete floors $(23.17 \%)$ (Table 3$)$.

\subsection{Isolation and identification of bacterial agents}

A total of 15 milk samples from strongly positive subclinical mastitis cases were examined for the isolation and identification of bacterial agents. The results of the isolated bacterial agents from strongly positive subclinical mastitis milk samples are presented in Table 4. Out of 15 samples, 02 samples were found containing mixed infection of Staphylococcus spp. and Streptococcus spp. and the rest 13 samples were associated with single infection.

Table 4: Prevalence of bacterial agents isolated from strongly positive subclinical mastitis cases

\begin{tabular}{llll}
\hline $\begin{array}{l}\text { No. of sample for } \\
\text { bacteriological culture }\end{array}$ & Bacterial isolates & $\begin{array}{l}\text { Number of } \\
\text { isolates }\end{array}$ & $\begin{array}{l}\text { Prevalence } \\
\text { rate }\end{array}$ \\
\hline \multirow{4}{*}{15} & $\begin{array}{l}\text { Staphylococcus } \\
\text { spp. }\end{array}$ & 11 & $73.33 \%$ \\
& $\begin{array}{l}\text { Streptococcus } \\
\text { spp. }\end{array}$ & 5 & $33.33 \%$ \\
Escherichia coli & 1 & $6.67 \%$ \\
\hline
\end{tabular}

\section{Discussion}

In this study, the overall prevalence of subclinical mastitis was $28.50 \%$ in lactating cows of Barisal, Bangladesh. This findings support the findings of Islam et al. (2011) who reported $29 \%$ overall prevalence of subclinical mastitis in lactating cows of Tangail, Bangladesh. Prodhan et al. (1996) reported a lower prevalence $(15.8 \%)$ of subclinical mastitis in cows of Baghabari milkshed area, Shirajgonj, Bangladesh. In this study, the prevalence of subclinical mastitis was significantly high in crossbreds $(45.28 \%)$ compared to local zebu $(22.45 \%)(\mathrm{p}<0.05)$. Kader et al. (2002) reported $46.6 \%$ prevalence of subclinical mastitis in crossbred lactating cows of Bangladesh, which is almost similar to the findings of the present study. A higher prevalence $(54.0 \%)$ of subclinical mastitis in cows in India was also reported by Singh and Baxi (1988). These differences of prevalence rates of subclinical mastitis might be due to difference of breeds of animals, management practices and the tests used for screening of the milk samples.

Age of animal might be an important factor to regulate the prevalence of subclinical mastitis in cattle. In the present study, a trend in increase in the rate of prevalence of subclinical mastitis was observed as the age of the animal increased (Table 3). The increase in subclinical mastitis with age is consistent with other studies (Kader et al. 2003, Ghosh et al. 2004, Radostits et al. 2000).

In this study, the prevalence of subclinical mastitis was influenced by the length of the lactation period and the highest prevalence based on the length of lactation was $32.50 \%$ found in mid lactation (90-180 days). The results are not in conformity with Pal and Verma (1988) who reported lower prevalence of subclinical mastitis in stages of lactation above five months. However, Rahman et al. (1997) reported higher prevalence $(34.00 \%)$ of subclinical mastitis during the $3^{\text {rd }}$ months of lactation.

In this study, the prevalence of subclinical mastitis was influenced by the parity of the animal and the highest prevalence was $42.86 \%$ found in $7^{\text {th }}$ parity of cows. This observation supports with the reports of Rasool et al. (1985) and Devi et al. (1997) who reported an increasing prevalence of subclinical mastitis with advancing parity.

Prevalence of subclinical mastitis was also found to be influenced by farm management system such as type of floor used for lactating cows in the study area. In this study, the prevalence of subclinical mastitis was higher $(32.69 \%)$ in lactating cows with earthen floor, whereas the prevalence was comparatively less $(23.17 \%)$ in lactating cows with concrete floor (Table 3).

In this study, Staphylococcus spp. was the most predominant isolates where prevalence was $73.33 \%$, which was followed by Streptococcus spp. (33.33\%) and Escherichia coli $(6.67 \%)$. The finding of this study is closely similar with the findings of Bitew et al. (2010) who reported $72.2 \%$ prevalence of Staphylococcus spp. in the both clinical and subclinical mastitis. 


\section{Conclusion}

The overall prevalence of subclinical mastitis in cows of Barisal district in Bangladesh was $28.50 \%$. Moreover, the prevalence of subclinical mastitis in crossbred cattle is more than that of local zebu cattle. From the results it also can be concluded that certain risk factors including age, breed, parity, lactation, floor type and daily milk yield may have been responsible for high prevalence of subclinical mastitis in lactating cows. The Staphylococcus spp. was most frequent bacterial agents associated with subclinical mastitis in cows in the study area. Good management might help in the reduction of prevalence of subclinical mastitis and for early detection of subclinical mastitis CMT can be performed on a regular basis as a control measure. By identifying the causal agent, the best antibiotic could be used to counter a specific bacterium species.

\section{Acknowledgement}

This research was funded by the Postgraduate Studies (Memo No. PSTU/PGS/P-06/07 (02)/14), Patuakhali Science and Technology University, Patuakhali, Bangladesh. The authors are also thankful to Md. Kamrul Islam and Shila Sarkar, Data Management Supervisors, Centre for HIV, ICDDR, B for their help in data analysis.

\section{References}

[1] Bitew M, Tafere A \& Tolosa T (2010), Study on bovine mastitis in dairy farms of Bahir Dar and its environs. Journal of Animal and Veterinary Advances 9, 2912-2917.

[2] Bradley A (2002), Bovine mastitis: an evolving disease. Veterinary Journal 164, 116-128.

[3] Cheesbrough M (1985), Medical laboratory manual for tropical countries. Vol. II: Microbiology, pp: 400-480.

[4] Dangore AD, Bhalerao DP, Jagadish S, Keskar DV \& Sharma LK (2000), Evaluation of some byre-side tests in bovine sub-clinical mastitis. Indian Veterinary Journal 77, 380-381.

[5] Devi BK, Shukla PC \& Bagherwal RK (1997), Incidence of subclinical mastitis in cows. Indian Journal Dairy Science 50, 477-478.

[6] Du Preeze JH (2000), Bovine mastitis therapy and why it fails. Jour nal of the South African Veterinary Association 71, 201-208.

[7] Fox LK (2009), Prevalence, incidence and risk factors of heifer mastitis. Veterinary Microbiology 134, 82- 88.

[8] Ghosh CP, Nagpaul PK \& Prasad S (2004), Factors affecting subclinical mastitis in Sahiwal cows. Indian Journal of Dairy Science 57, 127-131.

[9] Islam MA, Islam MZ, Islam MA, Rahman MS \& Islam MT (2011), Prevalence of subclinical mastitis in dairy cows in selected areas of Bangladesh. Bangladesh Journal of Veterinary Medicine 9, 73-78.

[10]Kader MA, Samad MA \& Saha S (2003), Influence of host level factors on prevalence and economics of sub-clinical mastitis in dairy cows in Bangladesh. Indian Journal of Dairy Science 56, 235-240.

[11]Kader MA, Samad MA, Saha S \& Taleb MA (2002), Prevalence and aetiology of sub-clinical mastitis with antibiotic sensitivity to isolated organisms among milch cows in Bangladesh. Indian Journal of Dairy Science 55, 218-223.

[12]Madut NA, Godir AEA \& El Jalil IM (2009), Host determinants of bovine mastitis in semi-intensive production system of Kharfoum State, Sudan. Journal of Cell and Animal Biology 3, 71-77.

[13]Merchant IA \& Packer RA (1967), Veterinary Bacteriology and Virology. $7^{\text {th }}$ Edn, the Iowa University Press, Ames, Iowa, USA, pp: 286-306.

[14]Prodhan MAM, Kamal AHM \& Mahbub-E-Elahi ATM (1996), Prevalence of subclinical mastitis in cows of Baghabari Milkshed area. Bangladesh Veterinary Journal 30, 59 - 61.

[15]Quinn PJ, Carter ME, Markey B \& Carter GR (2004), Clincal Veterinary Microbiology. Mosby Publishing, London, pp: 43-55, 327-344.

[16]Radostis OM, Gay CC, Blood DC \& Hinchcliff KW (2000), Veterinary Medicine: A Textbook of the diseases of cattle, sheep, pigs, goats and horses. $9^{\text {th }}$ Edn. WB Saunders Company Ltd. Philadelphia, pp: 603-700.

[17]Radostis OM, Gay CC, Hinchcliff KW \& Constable D (2007), Veterinary Medicine: A Textbook of the diseases of Cattle, Horses, Sheep, Pigs and Goats. $10^{\text {th }}$ Edn, Grafos, S.A. Arte Sobre Papel, Spain, pp: 823-835.
[18]Rahman MS, Nooruddin M \& Rahman MM (1997), Prevalence and distribution of mastitis in cross-bred and exotic dairy cows. Bangladesh Veterinary Journal 14, 1-4.

[19]Rasool G, Jabbar MA, Kazmi SE \& Ahmed A (1985), Incidence of sub-clinical mastitis in Nilli-Ravi buffaloes and Sahiwal cows. Pakistan Veterinary Journal 5, 76-78.

[20]Rosenberger G (1979), Clinical examination of cattle. $1^{\text {st }}$ Edn, Verlag, Paul Parey, Berlin, Germany, pp. 215-220.

[21] Sachin J \& Suresh G (2006), Status of mastitis as an emerging disease in improved and periurban dairy farms in India. Annals of the New York Academy of Sciences 1081, 74-83.

[22] Schultz LH, Broom RW, Jasper DE, Berger RWM, Natwke RP, Philpot WN, Smith JW \& Thompson PD (1978), Current Concepts of Bovine Mastitis. 2nd Edn., National Mastitis Council, Washington, DC, USA, pp: 6-9.

[23] Seegers H, Fourichon C \& Beaudeau F (2003), Production effects related to mastitis and mastitis economics in dairy cattle herds. Veterinary Research 34, 475-491.

[24] Singh KB \& Baxi KK (1988), Studies on the incidence and diagnosis of sub-clinical mastitis in milch animals. Indian Veterinary Journal 47 723-729.

[25] Singh PJ \& Sing KR (1994), a study of economic losses due to mastitis in India. Indian Journal of Dairy Science 47, 265-272.

[26] Sumathi BR, Veeregowda BM \& Amitha R (2008), Prevalence and antibiogram profiles of bacterial isolates from clinical bovine mastitis. Veterinary World 1, 237-238. 